\author{
Sławomir Sobieraj \\ Uniwersytet Przyrodniczo-Humanistyczny w Siedlcach \\ Wydział Nauk Humanistycznych \\ slawsob@wp.pl
}

\title{
Sławomir Sobieraj
}

Siedlce University of Natural Sciences and Humanities

Faculty of Humanities

slawsob@wp.pl

\section{TRANSGRESJE I WIWIFIKACJE. WANDY MELCER LIRYKA NOWOCZESNA}

\section{TRANSGRESSIONS AND VIVIFICATIONS. WANDA MELCER'S MODERN LYRIC POETRY}

Autor omawia w swoim artykule mniej znaną poezję Wandy Melcer. Opisuje jej związki ze sztuką i literaturą nowoczesną, a przede wszystkim z ruchem awangardowym. Analizuje wiersze, w których występują dysonansowe napięcia, charakterystyczne dla twórczości futurystów i ekspresjonistów. Podkreśla nowatorstwo analizowanych utworów pod względem strukturalnym (formuła wiersza wolnego, symultaniczność) i tematycznym (tu wskazuje na wątki urbanizacyjne i maszynizacyjne). Badacz dostrzega również kwestię feminizmu, która pojawia się w liryce pisarki jako jeden z wiodących tematów. Szerzej rozważa dwa zagadnienia: trangresji, czyli przekraczania zasad zwyczajności i obyczajowości oraz wiwifikacji, czyli animizacji otoczenia człowieka, które tworzy kultura materialna (świat rzeczy).

Słowa kluczowe: nowoczesność, Wanda Melcer, poezja polska, futuryzm, awangarda, ekspresjonizm, feminizm.

In his article the Author discusses the less-known poetry by Wanda Melcer. $\mathrm{He}$ describes its connections with the art and modern literature, and first of all with the avant-garde movement. The Author analyzes the poems in which the dissonant tensions, characteristic for the Futurism and Expressionism, occures. He underlines innovation of the analyzed poems in terms of their structural (the form of the free verse, simultaneousness) and thematic features (here he indicates motifs of urbanization and machinerization).

The researcher also notices the issue of the feminism, which appears in the lyric poetry of this writer as a one of the leading subjects. He also more broadly considers two other issues: transgression, i.e. crossing over the rules of ordinariness and dailiness, as well as vivification, i.e. animization of the surroundings of men, that creatsmaterial culture (the world of things).

Key words: modernity, Wanda Melcer, Polish poetry, futurism, avant-garde, expressionism, feminism. 


\section{Projekty nowoczesności a literatura}

Wanda Melcer primo voto Rutkowska, secundo voto Sztekkerowa (18961972) w dwudziestoleciu międzywojennym stała w pierwszym szeregu twórców zbuntowanych przeciw tradycji w sztuce i literaturze, a jednocześnie też zaangażowanych w szeroko pojętą działalność na rzecz przemian społecznych. Należała do reformatorów życia obyczajowego, współpracując m.in. z Tadeuszem Boyem-Żeleńskim oraz Ireną Krzywicką w walce o prawa kobiet oraz dzieci'. Opowiadała się za „nową sztuką”, której przyświecał cel dokonania w obszarze działań pisarzy rewolucyjnych zmian, dotyczących form i tematyki ich utworów. Nie tylko uczestniczyła w tworzeniu instytucji życia literackiego w odrodzonym państwie, m.in. Związku Zawodowego Literatów Polskich i oddziału krajowego PEN Clubu, ale ponadto podejmowała współpracę z awangardowymi pismami, jak np. Nowa Sztuka, Almanach Nowej Sztuki i Blok oraz innymi, o mniej radykalnej orientacji, które również mieściły się w tym kręgu (Gospoda Poetów, Ponowa), znajdując się w wyraźnej opozycji wobec uładzonego Skamandra. Trzymała stronę awangardy też później, gdy na walnym zgromadzeniu PEN Clubu w 1928 roku poparła w dyskusji Tadeusza Peipera, upominającego się o wprowadzenie przedstawiciela „nowej literatury” do zarządu tej organizacji ${ }^{2}$. Bez wątpienia, można ją uznać za orędowniczkę nowej literatury, a także nowego modelu życia, który w pierwszych dekadach dwudziestego wieku w sposób znaczący kształtowała ideologia postępu.

Samo pojęcie nowoczesności, której patronują Kartezjusz i Newton, zawiera w sobie projekt modernizacji świata nastawiony na przyszłość, na poszukiwanie epistemologicznych spełnień i wprowadzanie nowej organizacji stosunków społecznych. Zazwyczaj wiąże się z uwikłaniem w sieć racjonalistycznych przeświadczeń i praktyk zbiorowych, które prowadzą do ograniczenia indywidualnych praw i wyobrażeń w imię realizacji idei celowości, funkcjonalności i pożytku ogólnego. Jednakże mimo tego negatywnego aspektu i wystąpienia konfliktu jednostki ze społeczeństwem, na co zwraca szczególną uwagę Ryszard Nycz pisząc o doświadczeniu nowoczesności, podmiot jawi się w jej przekazie ,jako instancja aktywna, poddana refleksyjnej samokontroli, zdyscyplinowana i autonomiczna" (Nycz 2006: 8). A co najbardziej istotne, poszukując własnego sensu życia, podmiot ów wykracza poza doktrynalne nakazy i zakazy, ustanawiane zarówno przez dawne, jak i współczesne mu instytucje, które stoją na straży moralności i obyczaju bądź określają zasady obowiązujące w sferze kultury.

Rewolucyjne nastawienie wobec tradycji w kwestii norm obowiązujących w sztuce i w życiu jest cechą wspólną pokolenia młodych pisarzy polskich

1 Wanda Melcer była współzałożycielką powstałej w 1933 roku w Warszawie Ligi Reformy Obyczajów, pełniąc w niej funkcję sekretarza. Organizacja ta została powołana do życia jako krajowy oddział Światowej Ligi Reform Seksualnych.

2 Wspomina o tym poparciu Peiper w liście do Juliana Przybosia z 20 maja 1928 roku (Peiper 1974: 545-546). 
wkraczających na scenę literatury na początku lat międzywojennych. Podobne hasła, mniej lub bardziej zradykalizowane, głosili futuryści, skamandryci ${ }^{3}$ i awangardyści krakowscy. Wanda Melcer była ich rówieśniczką. Nurtowały ją te same problemy współczesności. Na początku międzywojnia, zarzuciwszy melancholijne poezjowanie w stylu młodopolskim, obecne jeszcze w jej debiutanckim tomiku wierszy Ptynące godziny, prezentuje zupełnie odmienne, nowoczesne podejście do twórczości literackiej jako działania kreatywnego, które przekracza bariery tradycji. W następnym tomie - Na pewno ksiażka kobiety — przedstawia opis teraźniejszości jako nowości wielowymiarowej: estetycznej, esencjonalnej i egzystencjalnej, tj. tożsamościowej. Ukazanie liryki Wandy Melcer w perspektywie nowoczesności będzie przedmiotem moich rozważań, mających na celu przede wszystkim obalenie obiegowej opinii o jej koligacjach ze skamandrytami i tradycjonalną poetyką (Czachowski 1936: 325-326), jak też wyjście poza schemat interpretacji jej wierszy, traktowanych wyłącznie jako egzemplum międzywojennej „poezji kobiecej” (Zawiszewska 2014: 362).

Bardzo często pisano wówczas o nowym początku i nowym człowieku w programach artystycznych i utworach stricte literackich. Znakiem czasu stało się mówienie nie tylko o wizji nowej poezji, ale także komentowanie własnych wierszy przez samych autorów. Literatura zyskiwała status projektu (przede wszystkim wśród przedstawicieli awangardy), analogicznie do inspirowanych zakończeniem wojny projektów nowego świata: w wymiarze spolecznym i politycznym.

„Izmy” związane z nową sztuką, która inspiracje czerpała z filozofii Nietzschego i Bergsona, ustaleń naukowych Einsteina, Freuda i Heisenberga, docierały do Polski z pewnym opóźnieniem i nie zawsze trafiały na podatny grunt. Mimo tego odegrały niemałą rolę w kształtowaniu się głównych idei i form polskiej literatury nowoczesnej.

Pojawili się u nas futuryści, formiści i ekspresjoniści, którzy w praktyce twórczej stosowali pomysły nawiązujące do wypowiedzi nie tylko swoich poprzedników z Zachodu, lecz także asymilowali niektóre idee, głoszone przez przedstawicieli innych kierunków artystycznych, jak chociażby kubizmu, dadaizmu i nadrealizmu. Ich następców z kręgu Zwrotnicy z Peiperem na czele oraz poetów Drugiej Awangardy należy uznać za kontynuatorów wielkiego ruchu modernistycznego, który ogarnął całą Europę, a za sprawą emigracji niektórych artystów szybko dotarł do Stanów Zjednoczonych Ameryki Północnej $j^{4}$.

3 Skamandryci również głosili idee opiewania życia zmodernizowanego, fascynowała ich kultura miasta i tłumu. Por. chociażby słowo wstepne z pierwszego numeru pisma, gdzie odnajdujemy następujące zdania: ,chcemy być słowem dnia dzisiejszego,chcemy tworzyć i budzić zachwyt nowoczesnegoczłowieka".

4 Jeden ze współtwórców ruchu dadaistycznego pisał po latach, że „Hiszpan Picabia, Francuz Duchamp oraz Amerykanin Man Ray stanowili twórczy triumwirat nowojorskiej szkoły dada" (Richter 1983: 167). 
Na różne sposoby powtarzane hasło odnowy świata, poparte gestem anarchizmu, od czasu futurystycznego manifestu Marinettiego sprowadzało się zazwyczaj do walki z tradycją. Poszukiwanie nowych wrażeń i tematów, fascynacja życiem tłumów oraz wielkich miast, dynamiką życia — to wszystko składało się na ducha czasów pierwszych trzech dekad dwudziestego wieku. Ów Zeitgeist to specyficzna atmosfera epoki cywilizacji technicznej, która oczarowuje magią swoich dokonań i jednocześnie rodzi katastroficzne odczucia. W pierwszych latach odrodzonej Rzeczpospolitej częściej dochodziły do głosu wizje pełne optymizmu. Tego rodzaju modernistyczne widzenie wciąż cechowało u schyłku lat dwudziestych minionego wieku Jana Brzękowskiego, który w jednym z esejów pisał o „wspólnym łożysku” wszystkich kierunków nowej sztuki, a jednocześnie próbował stawiać diagnozę na temat aktualnego jej stanu: „Najznamienniejszą cechą życia nowoczesnego jest jego szybkość i intensywność, najistotniejszym znamieniem nowej sztuki - pragnienie skrótu". Tym samym wskazywał na to, że styl eliptyczny stał się naczelną zasadą i walorem twórczości artystycznej nie tylko w poezji, ale też w prozie i filmie (Brzękowski 1929: 5-6).

Większość tendencji sztuki nowoczesnej była zakorzeniona w wieku dziewiętnastym, który stworzył utopijne projekty przyszłego ładu, „mającego zapewnić ludzkości rozumne rządy i sprawiedliwość". Najbardziej anarchistyczne wizje zmian w przestrzeni życia zbiorowego i sztuki, które odnajdujemy m.in. w utopizmie społecznym Proudhona, programie przewartościowania norm estetyczno-etycznych Nietzschego (Pękala 2000: 137-138), a także w poezji Baudelaire'a i innych symbolistów francuskich, kształtowały na początku dwudziestego stulecia nowe oblicze twórczości artystycznej. Opiewającej idee wolnościowe, zakładającej „realizację homo aestheticus w społeczeństwie przyszłości”, przypisującej sobie „określoną humanistyczną misję" (Morawski 1975: 76).

W Polsce po stronie nowej sztuki opowiadali się formiści (Witkacy i Czyżewski) i futuryści warszawscy, radykalni awangardyści z otoczenia Peipera oraz artyści z kręgu Bloku Stażewskiego i Żarnowerówny (Teresa Żarnower), jak również poeci poznańskiego Zdroju oraz autorzy związani z Ponową i Gospoda Poetów (Zob. Sobieraj 2018: 177-180).

To właśnie w Gospodzie Poetów współdziałała Wanda Melcer z Ksawerym Glinką — redaktorem naczelnym (i twórcą mającym w dorobku już wówczas dwa tomy wierszy), nadając pismu pewien rys nowoczesności. Ogłaszali tu oni swoje utwory, które szokowały ówczesnych odbiorców nieregularną wersyfikacją i brakiem rymu, tematyką związaną z życiem współczesnym (głównie w scenerii miejskiej) oraz bezpruderyjnością, wyrażającą się w manifestacyjnym lekceważeniu zasad obowiązujących w tradycyjnej obyczajowości i liryce. Wpływy futurystyczne i ekspresjonistyczne znalazły swój wyraz w przejawach biologizmu, który był zaprzeczeniem młodopolskiego modelu nastrojowości, np. w wierszu Melcer Koty (Sobieraj 2018: 187-189, 
193-195). Odnajdujemy tu nowoczesne potraktowanie uczucia, które jest dalekie od tkliwości, melancholii i nadmiaru egzaltacji. Poetka pisała o tym wprost $\mathrm{w}$ polemice $\mathrm{z}$ jednym $\mathrm{z}$ publicystów warszawskich:

Wzruszenie? Nie mogę powiedzieć, że widok tych kotów wzruszył mnie do łez i nie wymagam też łez od czytelnika, natomiast z pewną słusznością mogę twierdzić, że lubię bardzo zwierzęta i że ich widok zajmuje mnie, a co za tym idzie wzrusza (Melcer-Rutkowska 1920a: 12).

W tej samej wypowiedzi autorka Świętej kucharki odpowiadała na zarzuty przywiązanego do reguł klasycznej poetyki konserwatywnego krytyka (Pieńkowski 1920: 2) ${ }^{5}$, dając własną wykładnię nie tylko wzruszenia, ale też formy i rytmu. Odrzucała tradycyjne układy wersyfikacyjne, formuły gatunkowe i stopy rytmiczne na rzecz najlepszego sposobu „wyrażania tego, co się chciało powiedzieć" (Melcer-Rutkowska 1920a: 12). Głosiła tym samym pochwałę wiersza wolnego, który począwszy od pierwszych lat dwudziestego wieku powoli stawał się dominującą zasadą poezji; notabene, dotyczyło do także liryki Wandy Melcer, szczególnie tej z ostatniego zbioru.

Inny rodzaj przełamywania zasad tradycji w twórczości poetki zarysowuje jej wątek feministyczny. To manifestacja myśli o równouprawnieniu, które ma swoje realizacje uzyskać w wielu wymiarach życia współczesnego: intelektualnym, fizycznym, społecznym i obyczajowym. Przykłady na to znajdujemy zarówno w jej poezji, jak i w powieściach oraz reportażach.

Nie sposób nie zgodzić się z opinią, że polska historia literatury uprzywilejowuje teksty męskie", a kobiece marginalizuje (Araszkiewicz 2014: 10). Narodziny kobiecej podmiotowości w pisarstwie dwudziestolecia międzywojennego nie od razu zostały w pełni dostrzeżone i docenione przez krytyków i badaczy. W tych narodzinach niemały udział miała Wanda Melcer, inspirowana działalnością społeczną i literacką Zofii Nałkowskiej. Jednym z przejawów kształtowania się nowej tożsamości kobiecej, która przełamywała funkcjonujące jeszcze na przełomie 19. i 20. wieku tabu kobiety-autorki, naruszającej ogólnospołeczny konwenans (Kłosińska 1999: 95), była liczna grupa pisarek, które ogłaszały swoje teksty nie ukrywając się pod pseudonimami, jak to czyniły ich poprzedniczki jeszcze w okresie Młodej Polski (np. Maryla Wolska - Iwo Płomieńczyk i Anna Zahorska - Savitri). Wanda Melcer współkreowała swoistą „subkulturę kobiecą”, która objawiała się m.in. dużą częstotliwością występowania słowa „kobieta” bądź kobiecych imion i postaci w tytułach dzieł (Araszkiewicz 2014: 37). Była jedną z najbardziej rozpoznawalnych — obok Ireny Krzywickiej — pisarek nurtu feministycznego w okresie międzywojennym. Sama wyrażała swój akces do tej subkultury nie tylko w bardziej znanych powieściach (Józefina, Święta kucharka), ale też w drugim

5 Autor wątpił w wartość artystyczną wiersza o kotach, a jego autorce oraz innym twórcom Gospody Poetów z powodu preferowania „nowej formy” i rzekomego braku treści wypominał uleganie wpływom „kuźni socjalistycznej i żydowskiej” (Pieńkowski 1920: 2). 
zbiorze poezji: Na pewno ksiązka kobiety, uwydatniając w tytułowym okolicznikowym wyrażeniu tożsamość podmiotu utworu. Warto zauważyć, że tego rodzaju manifestacja kobiecości może być traktowana jako wejście w dyskurs nowoczesności wojującej o prawa emancypacji jednostkowej i tożsamościowej.

\section{Transgresje podmiotu lirycznego. Dysonanse i niespodzianki}

W okresie swojej aktywności poetyckiej, której kres przypada na rok 1921, autorka Plynących godzin, publikowała też wypowiedzi, zawierające ogólne sądy o sztuce słowa oraz koncepcje strategii lirycznych. W jednym z przeglądów literackich, dotyczących prasy i książek francuskich, wygłosiła wprost apologię epoki przemian, które znajdują odbicie również w literaturze:

Przez wszystkie rasy i narody idzie powoli potężna i nieunikniona fala, idzie i podnosi się do coraz większych wysokości. Przez wojnę i rewolucję stały się rzeczy, na które już niema rady. Próżne są wszelkie świadome i nieświadome chęci powstrzymania nadchodzących wypadków, bo to, co nadejdzie już się właściwie stało, już jest konsekwencją przemiany.

Pisma ludzi i książki przez wszystkie granice połączyło w jedno to, co nadchodzi [...] (Melcer-Rutkowska 1921b: 275).

Obok jej uwag o „nowej uczuciowości” i nowych ekscentrycznych formach poematów, snutych na marginesie rozważań o nowatorskich dziełach Nicolasa Beauduina, Alberta Gleizesa, Tristana Tzary i Francisa Picabii (a więc przedstawicieli rozmaitych kierunków awangardowych), znajdziemy wyraz świadomości modernistycznej i zaangażowania w — jej zdaniem — powszechny proces modernizacji świata:

Połączenie natężenia wszystkich wysiłków w kierunku realizowania najwyższych zamierzeń ducha ludzkiego, oto jest cel jasny i wszystkim widoczny. I dlatego łączą się ludzie wszystkich krajów i zaś, dlatego zapominają o tern, co ich dzielić mogło kiedykolwiek (Melcer-Rutkowska 1921b: 276).

Publicystka dostrzega i pochwala jednoczesność oraz współzależność zjawisk reformatorskich $\mathrm{w}$ różnych dziedzinach ludzkiej działalności, pisząc o takowych w obszarze sztuki i życia społecznego. Przekonując czytelnika do swoich przekonań i poglądów, stosuje styl perswazyjny i obrazowy. Głosi niezachwianą wiarę w możliwość realizacji „wielkich zadań” i nieograniczoność możliwości, krytykuje sceptycyzm i bezczynność jako cechy wcześniejszej formacji.

Można sądzić, że bliskie były jej hasła przebudowy sztuki i świata, głoszone przez radykalnych awangardystów, tj. futurystów, kubistów, a nawet dadaistów. Marinetti, który w pierwszym manifeście futurystycznym potraktował kobiety przedmiotowo, upominał się jednak o równe prawa dla obydwu płci (Lista 2002: 32). Głosił też nową obyczajowość, uwolnienie żony od podporządkowania mężowi i w ogóle wolne związki. 
W jednym z numerów Echa Literacko-Artystycznego z 1914 roku, pisma, w którym publikowała również w tym samym czasie Wanda Melcer, ukazał się artykuł o futuryzmie autorstwa innej działaczki ruchu kobiecego w Polsce i pisarki, Anny Limprechtówny. Zawierał on oprócz streszczenia obszerne fragmenty manifestu założyciela ruchu, w których poruszone zostały także kwestie kobiece. Marinetti mimo kontrowersyjnych sądów o kobietach (dowodził ich niższości wobec mężczyzn), widział w nich sprzymierzeńców w procesie rewolucjonizowania świata i walki z przesądami. A polska komentatorka zajęła w stosunku do tego ruchu stanowisko dość ambiwalentne. Mimo dezaprobaty dla pogardy wobec kobiet, wyrażała nadzieję, że stanie się on początkiem postępowej drogi:

Jak każdy młodzieńczy wybuch długo tłumionego niezadowolenia, futuryzm grzeszy dziką przesadą i brutalną bezwzględnością, która nieopatrznie pali za sobą wszystkie mosty. Rażą nas również jego burzliwe zamiary względem wszystkiego, co nam przeszłość najpiękniejszego i najdrogocenniejszego pozostawiała, jako też nieuzasadniona pogarda dla kobiety i rodziny.

Jeżeli jednak pohamuje swe zawadiactwo, otrząśnie się z bezkrytycznej zarozumiałości i oczyści swój program z ideowych dziwolągów, a oprze się na miłości nowych, niezależnych dróg i pracy nad ekonomicznym podniesieniem ojczyzny, może futuryzm, jako drożdże postępu, stać się kiedyś podwaliną społeczno-państwowej potęgi Włoch (Orsyd 1914: 18).

To właśnie idea postępu i przekraczania ograniczeń przyświeca całej twórczości literackiej Wandy Melcer, a więc także poezji. Transgresyjność jej wierszy znajduje wyraz zarówno w tematyce i konstrukcji podmiotu mówiącego jej wierszy, jak również w ich nowatorskiej formie.

Nie mamy tu do czynienia z liryką konfesyjną, nawet gdy odsłania ona kobiece widzenie świata $\mathrm{z}$ intencją uczynienia z niego manifestacji swojej tożsamości płciowej. Ale też nie chodzi chyba tak bardzo autorce o sfeminizowanie wypowiedzi, a raczej o ukazanie możliwej inności narracji. Odkrywanie odmiennej rzeczywistości.

W kilku jej ważnych tekstach żeński podmiot liryczny jest wykreowany na jednostkę niezależną, pewną siebie, o cechach zdobywcy nastawionego na poznawanie i podbijanie nowych rejonów świata, czym przypomina bohaterów twórczości futurystów, a także wcześniejszych poetów, jak np. Walt Whitman i Émile Verhaeren, którzy inspirowali twórców awangardowych. Przypomina także postawę silnego mężczyzny. Nawet chce z nim rywalizować o palmę pierwszeństwa, jak w wierszu Atalanta z tomu Na pewno książa kobiety. Oto współczesny wzorzec feminy - wyzwolonej, wysportowanej i nie znającej lęku bądź słabości, uczuć, które jej przypisywała tradycyjna kultura:

Nikt mnie nie może prześcignąć.

Kiedy się zerwę, chyża, do biegu, daleko w tyle zostawiam współzawodników. 
Spojrzyj na moje nogi, zwięzłe, mocne, polotne, spójrz na wiązania stopy, na kostkę, ścięgna i palce!

[...]

Za nic mi czas i przestrzeń, Ja biegnę, Atalanta! [...]

(Melcer-Rutkowska 1920b: 17)

W wierszu Zarozumiatość bohaterka również ujawnia swoje pragnienia i niezwykłe ambicje. Chce przekraczać granice zwyczajności i przeciętności, role wyznaczane jej przez dziewiętnastowieczne mieszczańskie zasady życia obyczajowego. Nie zgadza się, by „przygładzano” ją jak „kwiatek na ścianie”. $\mathrm{Z}$ całą świadomością podejmowanego ryzyka sprzeciwia się staremu ładowi społecznemu i manifestuje młodzieńczą energię, która — jej zdaniem — gwarantuje realizację nowych idei:

[...] stanęłam na wielkim placu i oznajmiłam, że jestem.

Cóż wy zrobicie z taką, na jakie wpiszecie mnie listy, że chcę mieć i kota, i perły, i chcę być prezesem ministrów ?

Nie zabijecie mnie kulą, ni mieczem, jak Heljogabal ja przecież jestem młodością i idę tańczyć na bal. Minęłam was, przeszłam mimo, żyć mi się strasznie podoba, młoda jestem i piękna, och, jakże piękna i młoda!

(Melcer-Rutkowska 1920c: 8).

W tym dość optymistycznie brzmiącym monologu można jednak się doszukać pewnych napięć. Obok deklaracji śmiałych czynów, mijania tych, którzy są strażnikami przeszłości i jej norm, pojawia się jednak nuta niepewności i obawy przed napiętnowaniem z ich strony. Wprowadza ją przywołanie imienia cesarza rzymskiego Heliogabala, zamordowanego przez pretorian wskutek niechęci ze strony obywateli, których bulwersowały niemoralne uczynki i ekstrawagancje seksualne władcy.

Lekko zarysowane wewnętrzne napięcie osoby mówiącej jest symptomem swoistego dualizmu, a raczej dysonansu. Podobny stan ducha można dostrzec w postawie Atalanty, która prosi o uczciwe reguły wyścigu i nie rzucanie pod nogi złotych hesperyjskich jabłek, które przeszkadzałyby w biegu. W świadomości bohaterek pozostaje wiara $\mathrm{w}$ spełnienie ideałów mimo przewidywania pewnych trudności. 
W świetle rozważań Hugo Friedricha zawartych w klasycznej już rozprawie Struktura liryki nowoczesnej, nowoczesną twórczość poetycką, której początek wyznaczają Baudelaire, Rimbaud i Mallarmé, cechuje właśnie przede wszystkim „dysonansowe napięcie”, przejawiające się w treści i formie:

Jeżeli nowoczesny wiersz dotyczy rzeczywistości — rzeczy lub ludzi - to traktuje o niej nie opisowo i nie z ciepłem przyjaznego widzenia i odczuwania. Prowadzi on rzeczywistość ku nieznanemu, wyobcowuje ją i deformuje. Wiersz nie pragnie też już być osądzony wedle tego, co potocznie nazywa się rzeczywistością, nawet wtedy, gdy sam wchłonął jej cząstkę - jako odskocznię dla swej wolności. Rzeczywistość uwolniona jest od przestrzennego, czasowego, rzeczowego i duchowego porządku i unika tym samym rozróżnień [...] niezbędnych przy normalnym widzeniu świata: między pięknem a brzydotą, bliskością i dalą, między światłem i cieniem, bólem i radością, ziemią i niebem. Spośród trzech możliwych zachowań poezji lirycznej — czucia, obserwacji, przemiany — dominuje w poezji nowoczesnej ostatnie, i to zarówno w odniesieniu do świata, jak i do języka (Friedrich 1978: 32-33).

Przemiana i zaskoczenie - te atrybuty literatury awangardowej przenikają do utworów Wandy Melcer. Kilka przykładów oryginalnego konceptu wiersza odnajdujemy już w debiutanckich Ptynacych godzinach, gdzie poprzez wprowadzenie cyklicznej struktury autorka uzyskuje nowatorski efekt zróżnicowania poetyki. Co prawda, wynika też on z faktu włączenia do zbioru wieloczęściowego poematu nastrojowo-symbolicznego Szwajcaria, który powstał kilka lat wcześniej. Ale obok niego występuje tu poetycko-dramatycznie skonstruowana opowieść - z rozpisaniem na role - Perwersyjna księżnicz$k a$. Sam pomysł, raczej nieudany pod względem fabularnym, oparty na dysonansach stylistycznych i językowych, przedstawiający banalną historię kobiety z wyższych sfer, która szuka zaspokojenia swoich pragnień erotycznych w różnych kręgach społecznych, przynosi kilka tekstów dość wysokiej próby artystycznej, o zabarwieniu ironicznym i żartobliwym.

Obok urokliwej miniatury Kaprys, która może stanowić klucz do rozumienia związków bohaterki z mężczyznami (przeglądanie się w „zwierciadle duszy" innych osób) i kończy się niespodziewanym nawiązaniem do filozofii Leibniza, uwagę zwraca Gotowalnia:

Nie, nie mam duszy. Czytaj swoje poematy, w twoich słowach tak było mi zawsze do twarzy, lecz nie wmawiaj mi duszy, co też ci się marzy, nadworny rymopisie. W pomysłyś bogaty.

Dusza moja naskórek ma koloru ciała, dlatego muszę zgoła wątpić w jej istnienie. Bo czymże się od ciała różni? Nie ocenię, nadto jest rudowłosa, szalona i biała. 
Podaj lustro. Czym znowu zanadto niemiła?

Nie chcesz wierzyć? Poeto, nikt cię nie przymusza.

Puder na brwiach i rzęsach ma dziś moja dusza, nie zdążę zetrzeć, schadzki godzina wybiła...

(Melcer 1917: 66).

Ewidentnie, wyrzeczenie się duszy, zwątpienie w jej istnienie, wreszcie identyfikacja duszy z ciałem - zaskakujące ze względu na bezpośredniość skojarzeń deklaracje podmiotu lirycznego, który sprzeciwia się uczuciowości sentymentalnej, tworzą dyskurs krytyczny wobec obyczajowości i kultury dotychczasowej, tj. mieszczańskiej. Sens wiersza doskonale koresponduje z przesłaniem sztuki nowoczesnej, stawiającej sobie za cel m.in. walkę ze stereotypowymi wizjami rzeczywistości ${ }^{6}$. Natomiast odwołanie do poezji, która służy jedynie zaspokojeniu oczekiwań i gustów odbiorców, pozwala na wprowadzenie innego, a mianowicie kreacyjnego modelu działania. Można go odnieść również do działań artystów. Garderoba kobieca (a przypominająca teatralną), zwana tutaj gotowalnią ${ }^{7}$, staje się miejscem przemiany nie tylko fizycznej, ale także mentalnej, żeby nie powiedzieć tożsamościowej. Bohaterka, jak artystka sceniczna, gra tutaj swoją rolę, gra siebie - z pełną świadomością tego, co czyni.

To tylko jeden z przykładów manifestacji antymłodopolskich w debiutanckim zbiorze, który rozpoczyna się od wierszy, zrywających z poprzednią epoką, jej melancholią i nastrojowością niemocy na rzecz dynamizmu, wyzyskiwania energii wewnętrznej i pochwały życia (Tesknica, Samotność). Wyrażana przy użyciu języka symbolicznego idea transgresji podmiotu lirycznego, zawiera pogłos Nietzscheańskiej koncepcji człowieka twórczego, który czuje wewnętrzną moc i nakazuje sobie: „niechaj piorunowa będzie twoja samotność" (Melcer 1917: 8).

Mamy zatem do czynienia również z nową konstrukcją ja lirycznego, podmiotową i dynamiczną. Ja transgresyjne często oddaje kult życiu, które staje się dla niego wartością nadrzędną. W związku z powyższym niejednokrotnie dostrzegamy w wierszach Wandy Melcer konflikt, jaki zarysowuje się między prawie dionizyjskim zachwytem nad istnieniem a społecznie zalegalizowanymi zasadami współżycia i obyczaju. Opozycja ta, sytuująca się na linii: życie niezależne - kultura i konwencja - jest jedną z kluczowych kategorii nowoczesności w literaturze (Markowski 2007: 37).

${ }^{6} \mathrm{Na}$ ten aspekt nowoczesności w literaturze zwracał uwagę Michał Paweł Markowski, odwołując się do przemyśleń wybitnych polskich krytyków literatury: Stanisława Brzozowskiego w Legendzie Młodej Polski i Stanisława Baczyńskiego w Sztuce walczacej (Markowski 2007: 31).

7 Gotowalnia to według słowników z drugiej połowy wieku XIX — „toaleta ze wszystkimi przyborami do ubierania się i trefienia włosów", zob. Słownik języka polskiego podług Lindego i innych nowszych źródet, t. I, oprac. E.[Erazm] Rykaczewski, Berlin - Warschau 1866, s. 204. Podobnie w słowniku Lindego (Linde 1855: 108). 


\section{Wiwifikacje}

Prymat życia wraz z jego bogactwem, różnorodnością i zmiennością oraz towarzysząca mu różnorodność poetyki odróżniały awangardystów — takich jak np. Apollinaire (Ważyk 1980: 10) — od postępowych w wymiarze kulturowym, a przywiązanych do tradycyjnych sposobów wyrazu poetów z kręgu Skamandra. Wanda Melcer, mimo publikacji kilku wierszy w piśmie Mieczysława Grydzewskiego i spółki, częściej niż oni szukała nieszablonowych rozwiązań warsztatowych, budowała swoje teksty w sposób oryginalny i zaskakujący niezwykłym konceptem.

Tak jak kilka lat później w roku 1922, zapewne inspirowany poezją kubistów, pisał Tadeusz Peiper o metaforze teraźniejszości, która bazowała na „change de place w hierarchii różnych dziedzin świata” (Peiper 1972: 57), tak też autorka Plynacych godzin w swoich wierszach mieszała (,,amalgamowała" - używając leksyki stosowanej redaktora Zwrotnicy) sferę rzeczy i myśli prozaicznych z pojęciami i uczuciami wyższego duchowego szczebla. Przykładem może być Piosnka kaloryferów. Poetka wzorem futurystów waloryzuje tutaj nowy świat technicznych wynalazków, nadając mu czarodziejski i magiczny wymiar:

Idę, idę, oto nadchodzę,
woda ciepła, woda żywa,
wchodzę radośnie w białe rury,
śpiewam piosenkę cichą, cichutką,
[...] jeden z uczni czarnoksiężnika,
zdołał wreszcie mnie pochwycić,
kazał mi chodzić bardzo cicho,
kazał mi śpiewać, zawsze śpiewać,
cichą piosenkę, wdzięku pełną

(Melcer-Rutkowska 1920b: 12).

Podobnie określał to Peiper: „Człowiek dzisiejszy nie ma powodu widzieć w słońcu nic więcej nad złotą cętkę, ma zaś prawo w guziku od spodni upatrywać zwierciadło swojej własnej wielkości” i dodawał, że znamienną cechą najnowszej liryki ,jest ożywianie materii, albo raczej: podnoszenie materii na wyższy stopień życia”. W tych rozważaniach o współczesnej metaforze pojawia się jeszcze inna nazwa: „vivifikacja”, która oznacza ożywienie rzeczy martwych bądź istnień o niskim poziomie biologicznego rozwoju (Peiper 1972: 57-58). Zarówno w praktyce poetyckiej Wandy Melcer, jak i w liryce oraz publicystyce Peipera, dochodzi do „kulturowego uświęcania” przedmiotów” (Bourdie 2006: 601).

W swoich wiwifikacjach poetyckich Melcer problematyzuje banalne z pozoru zdarzenia życiowe, snuje opowieści rozgrywające się w scenerii otaczających ja liryczne przedmiotów bądź przyrody. W utworze $U$ fryzjera wyposażenie zakładu stwarza aurę niezwykłości, a zarazem „miły przybytek 
wdzięku, gdzie mizdrzy się damskość", będąca wyzwaniem rodzaju męskiego (Melcer-Rutkowska 1920b: 14). Natomiast w Trawie pojawia się gra słowna, pobudzająca do pogłębionej refleksji o niemożności wypowiedzenia wszystkich myśli i uczuć przy pomocy słowa. To są napięcia charakterystyczne dla poezji nowoczesnej, która jest nastawiona na odkrywanie komunikacyjnych komplikacji, na ukazywanie krytycznego podejścia do nieograniczonych możliwości ludzkiej mowy, wreszcie na przekraczanie percepcji potocznej i odsłanianie stanów epifanii. Tytułowa aluzja, odsyłająca do potocznego wyrażenia „mowa-trawa” (czyli słowa bez treści), kreuje niejasną sytuację liryczną:

Chodź i posłuchaj,

bo mam ci coś do powiedzenia.

Nie bardzo wiem, co to jest,

i jakby ci to określić, ażebyś łatwiej zrozumiał.

Muszę ci coś powiedzieć,

coś wąskiego, coś zielonego,

muszę ci coś powiedzieć,

co ma pod ziemią kłącze, długie splątane korzonki.

Chwieje się lekko od wiatru,

pochyla się, pochyla,

a potem znów się pochyla

w inną zupełnie stronę.

Rano jest mokre od rosy, mokre od rosy, niebieskie, w południe znowu zielone, miękkie, wąskie, zielone.

Kazano mi tobie powiedzieć,

Nie wiem dokładnie, co

(Melcer-Rutkowska 1920b: 33).

Zabawa słowna, zainicjowana tytułem, rozwija się dzięki stylizowaniu dyskursu na nieskładny kolokwialny monolog, przepełniony powtórzeniami. Być może to, co ma do powiedzenia osoba mówiąca, ma związek z niezwykłym przeżyciem, być może, jest to tylko gra z odbiorcą. Trawa - symbol niejasności i natury nieogarnionej, uzyskuje status wyższego sensu, nieodgadnionych myśli i stanów uczuciowych.

Podobny rodzaj wiwifikacji, rozumianej jako rozbudowana, szeroko zakreślona metafora, znajdujemy w wierszu, którego inspiracją jest domowe akwarium. Imitacja żywiołu - swoisty rodzaj rozrywki — została poddana znaczącej translokacji, połączona $\mathrm{z}$ wyimaginowanym rozległym obszarem wodnym:

Akwarium moje tajemnie łączy się z morzem.

Każda fala przypływa o brzeg blaszany potrąca, śpiewa cicho, trącając, i cofa się, i kołysze, druga ją trąca, kołysze, w śpiew się zamienia i w ciszę, o brzeg blaszany potrąca, posłuszna prawom miesiąca. 
[...] Akwarium moje tajemnie łączy się z morzem.

Dziś rano cztery delfiny wpłynęły do mego mieszkania, z ich nozdrzy tryskały fontanny pod sufit świeżo bielony, $\mathrm{w}$ wodę spienioną i białą biły rytmiczne ogony, ciężko dyszały cielska, zbudziły mnie ze spania.

Akwarium moje tajemnie łączy się z morzem.

Nałożę na siebie skafander, i z twarzą w hełmie ukrytą rzucę się w wodę akwarium, pod szkłem nurkując zielonem, morze pójdę odwiedzić, ukryte za alg festonem, morze, co do mnie codziennie przychodzi z poranną wizytą (Melcer-Rutkowska 1921a: 46) ${ }^{8}$.

Bohaterem wiersza jest eksplorator niezmierzonych przestrzeni i nieznanych zjawisk - przenośnie morza, świata, który otacza jednostkę i z którym musi się ona codziennie mierzyć. Nurkowanie w skafandrze i hełmie jest tu metaforą podboju świata, projektu nadającego sens ludzkiemu życiu. Podmiot, ukierunkowany na rozwój i odkrywanie nieznanego, ujawnia swoją refleksyjną naturę i aktywistyczne nastawienie do życia. Tym samym deklaruje przynależność do formacji nowoczesnej, która docenia odkrycia i wynalazki naukowe oraz techniki.

Oczywiście, w tym wypadku koncept wiersza sprowadza się jedynie do tematyzacji współczesności, a sama jego idea jest dość banalna. Mimo formalnego przekraczania poetyki realizmu, samo przedstawienie rzeczywistości ma charakter mimetyczny. Opiera się na prostej analogii.

Bardziej oryginalnym przykładem wyobraźni kreacyjnej, która „dąży nie do naśladownictwa, lecz do przekształcenia" (Friedrich 1978: 80), jest miniaturowy utwór Wandy Melcer pt. Tęsknota:

Tęsknota za jednym okiem podstępnie wyjętym z głowy: kiedy ciebie nie ma przy mnie widzę tylko pół świata

(Melcer-Rutkowska 1920b: 28).

Obrazowanie przemian cywilizacyjnych związanych z maszynizacją i urbanizacją świata pierwszych dekad dwudziestego wieku jest u Melcer dość bogate. To potwierdza jej związki z nowoczesnością, identyfikowaną z ideą postępu cywilizacyjnego. Pejzaże miast, apologia techniki i elektryczności to częste motywy jej wierszy. Towarzyszy im zazwyczaj pozytywna aura, choć z rzadka wkradają się akcenty niepokoju egzystencjalnego (np. w utworach z tomu Na pewno ksiażka kobiety: $W$ obcym mieście, O mnie). Szczególny wymiar uzyskują zwłaszcza w wierszach o proweniencji ekspresjonistycznej. Wpływy futuryzmu i kubizmu są również dostrzegalne w jej dorobku poetyckim.

8 W cytowanym tekście uwspółcześniono pisownię słowa „akwarium”. 
Przede wszystkim należy zwrócić uwagę na stronę formalną utworów, mających wiele wspólnego z awangardowym eksperymentowaniem. Mowa tu o preferowaniu wiersza wolnego, licznych przerzutniach, symultaniczności przedstawień (Sobieraj 2018: 197) i poetyce fragmentu (Sobieraj 2019: 242). Jednak nie mniej ważne od warsztatowych „rewolucji”, którym nie zawsze poetka była wierna, są jej deklaracje ideowe, wchodzenie w dyskursy nowoczesności, prowadzone na gruncie walki ze stereotypami obyczaju, reguł życia społecznego i sztuki.

\section{LITERATURA}

Araszkiewicz Agata. „Wstęp. Kobiece dwudziestolecie”. Zapomniana rewolucja. Rozkwit kobiecego pisania $w$ dwudziestoleciu międzywojennym. Warszawa 2014: 9-59.

Bourdie Pierre. „Dystynkcja”. Tłum. Piotr Biłos. Teorie literatury XX wieku. Antologia. Red. Anna Burzyńska i Michał Paweł Markowski. Kraków 2006: 595-602.

Brzękowski Jan. „Kilometraż”. L’art Contemporain. Sztuka Wspótczesna 1 (1929): 5-6.

Czachowski Kazimierz. Obraz współczesnej literatury polskiej 1884-1934. T. III: Ekspresjonizm i neorealizm. Warszawa - Lwów 1936.

Friedrich Hugo. Struktura nowoczesnej liryki. Tłum. i wstęp Elżbieta Feliksiak. Warszawa 1978.

Kłosińska Krystyna. „Kobieta autorka”. Ciało, pożądanie, ubranie. O wczesnych powieściach Gabrieli Zapolskiej. Kraków 1999: 7-37.

Linde Samuel Bogumił. Słownik języka polskiego. Wyd. drugie, poprawne i pomnożone. T. II. Lwów 1855.

Lista Giovanni. Futuryzm. Tłum. Ewa Gorządek. Warszawa 2002.

Markowski Michał Paweł. Polska literatura nowoczesna. Leśmian, Schulz, Witkacy. Kraków 2007.

Melcer Wanda. Ptynace godziny. Warszawa 1917.

Melcer-Rutkowska Wanda. „Apologia 'Kotów”. Gospoda Poetów 2 (1920): 11-12. (1920a)

Melcer-Rutkowska Wanda. Na pewno ksiażka kobiety. Warszawa 1920. (1920b)

Melcer-Rutkowska Wanda. „Zarozumiałość”. Gospoda Poetów 3 (1920): 8. (1920c)

Melcer-Rutkowska Wanda. „Akwarium”. Ponowa 1 (1921): 46. (1921a)

Melcer-Rutkowska Wanda. „Kilka pism i książek z Francji”. Ponowa 3 (1921): 275-277. (1921b)

Morawski Stefan. „Sztuka i anarchizm”. Teksty 2 (1975): 59-83.

Nycz Ryszard. „O nowoczesności jako doświadczeniu”. Teksty Drugie 3 (2006): 4-9.

Orsyd [Anna Limprechtówna]. „Futuryzm”. Echo Literacko-Artystyczne 1 (1914): 18.

Peiper Tadeusz. „Metafora teraźniejszości”. Tędy. Nowe usta. Oprac. Stanisław Jaworski. Kraków 1972: 54-61.

Peiper Tadeusz. O wszystkim i jeszcze o czymś. Artykuty, eseje, wywiady (1918-1939). Przedmowa i komentarz Stanisław Jaworski. Kraków 1974.

Pękala Teresa. Awangarda i ariergarda. Filozofia sztuki nowoczesnej. Lublin 2000.

Pieńkowski Stanisław. „Gospoda Poetów” [II]. Gazeta Warszawska 296 (1920): 2.

Richter Hans. Dadaizm. Sztuka i antysztuka. Tłum. Jacek St. Buras. Warszawa 1983.

Stownik języka polskiego podtug Lindego i innych nowszych źródet. T. I. Oprac. E. [Erazm] Rykaczewski. Berlin - Warschau 1866.

Sobieraj Sławomir. „Środowisko ‘Gospody Poetów”. Awangarda mniej znana. Przypadki poezji. Siedlce 2018: 173-200.

Sobieraj Sławomir. „Zapomniana poezja Wandy Melcer-Rutkowskiej”. Conversatoria Litteraria". 2019. T. 13: 233-246.

Ważyk Adam. „Wstęp”. Guillaume Apollinaire. Wybór pism. Wstęp i opracowanie Adam Ważyk. Warszawa 1980: 5-69.

Zawiszewska Agata. Między Młoda Polska, Skamandrem i Awangarda. Kobiety piszace wiersze $w$ dwudziestoleciu międzywojennym. Szczecin 2014. 


\section{Славомир Собјерај}

\section{ТРАНСГРЕСИЈА И ВИВИФИКАЦИЈА. ВАНДА МЕЛЦЕР - САВРЕМЕНА ПОЕЗИЈА}

\section{Резиме}

Аутор у овом раду обрађује мање познату поезију Ванде Мелцер, описује њену повезаност са савременом уметношћу и књижевношћу - у првом реду са авангардним покретом. У раду се анализирају песме у којима се испољавају дисонантне напетости карактеристичне за стваралаштво футуриста и експресиониста. Наглашена иновативност анализираних текстова из угла структуре (формула слободног стиха, синхроност) и садржаја (ту она наглашава теме урбанизације и механизације). Истраживач се такође дотиче и питања феминизма који се у списатељичиној поезији појављује као једна од водећих тема. Подробније се разматрају два питања: трансгресија или прекорачење устаљених правила и обичаја и вивификација, тј. анимизација човекове околине која је условљена материјалном културом (свет ствари).

Кључне речи: савременост, Ванда Мелцер, пољска поезија, футуризам, авангарда, експресионизам, феминизам. 